\title{
Comparison of Soft Tissue Changes Between Two Class II - Malocclusion Treatment Protocols: with and without Extractions Associated to Intermaxillary Elastics
}

\section{Comparação das Alterações em Tecidos Moles entre Dois Protocolos de Tratamento para Má Oclusão de Classe II: Com e sem Extração Associado ao Uso de Elásticos Intermaxilares}

\author{
Honório Tóttoli Segundo a; Victor França Didier*b; Renata Rodrigues de Almeida-Pedrinc ${ }^{\mathrm{b}}$; Ana Cláudia de Castro \\ Ferreira Conti ${ }^{\text {b; }}$ Marcio Rodrigues de Almeida ${ }^{\text {; }}$, Danilo Pinelli Valarelli ${ }^{c}$ \\ annisagrado - Centro Universitário Sagrado Coração, Orthodontic Department. SP, Brasil. \\ ${ }^{b}$ Unopar, Orthodontic Department. PR, Brazil. \\ 'Private Practice. Orthodontics. SP, Brazil \\ *E-mail: victordidier_@hotmail.com \\ Recebido em: 30/06/2020 \\ Aprovado em: 27/11/2020
}

\begin{abstract}
The literature is scarce on the intermaxillary elastics impacts on soft tissue during the treatment of Class II malocclusion The purpose of the present study was to compare the soft tissue changes after the treatment of Class II malocclusion using intermaxillary elastics with and without the premolars extraction. The sample consisted of 41 patients Class II Division 1 malocclusion with bilateral molar relationship of at least $1 / 2$ cusp, divided into two groups. Group 1: 21 patients (mean age 18.97 years) treated for a mean period of 3.15 years with intermaxillary elastics without dental extractions. Group 2: 20 patients (mean age,17.40 years) treated for a mean period of 3.07 years with intermaxillary elastics and extraction of two maxillary premolars. Lateral cephalometric radiographs were used to measure the soft tissue and incisor variations before and after orthodontic treatment. Dolphin Imaging Premium software was used for radiographic analysis. Groups 1 and 2 were highly similar concerning age, initial overjet, molar relationship, treatment time, and initial cephalometric measurements. Statistically significant differences between both groups were observed $(P<0.05)$ related to the anteroposterior position of the lower lip in Group 2 and facial convexity angle in Group 1. Conclusions: Both treatment modalities promoted similar effects on the facial profile, except for the greater retrusion of the lower lip in the protocol with extractions and decrease in the facial convexity in the protocol without extractions.
\end{abstract}

Keywords: Malocclusion. Angle Class II. Orthodontics. Orthodontic Anchorage Procedures. Tooth Extractions

\section{Resumo}

A literatura é escassa quanto ao impacto dos elásticos intermaxilares nos tecidos moles durante o tratamento da má oclusão de classe II. O objetivo deste trabalho foi comparar as alterações tegumentares do tratamento da má oclusão de Classe II com elásticos intermaxilares sem extração e com extrações de pré-molares. A amostra retrospectiva foi de 41 indivíduos que apresentavam no início do tratamento relação molar de no mínimo 1/2 Classe II bilateral e foram divididos em dois grupos. Grupo 1: 21 pacientes (média de idade inicial de 18,97 anos), tratados por um período médio de 3,15 anos, sem extrações e com uso elásticos intermaxilares; Grupo 2: 20 pacientes (média de idade de 17,40 anos), tratados por um periodo médio de 3,07 anos, com extrações de dois pré-molares superiores e elásticos. As telerradiografias foram usadas para aferir as medidas tegumentares e a variação dos incisivos antes e depois do tratamento ortodôntico através do software Dolphin Imaging Premium 11.7. Ambos os grupos mostraram alto grau de compatibilidade nos quesitos idade, overjet inicial, relação molar, tempo de tratamento e medidas cefalométricas iniciais. Os resultados ao final do tratamento mostraram diferença estatisticamente significante entre os grupos $(p<0,05)$ na posição anteroposterior do lábio inferior (Grupo 2) e no ângulo de convexidade facial (Grupo 1). Conclusões: As duas modalidades de tratamento promovem efeitos semelhantes no perfil facial, exceto pela maior retrusão do lábio inferior no protocolo com extrações e diminuição da convexidade facial no protocolo sem extrações.

Palavras-chave: Má Oclusão de angle classe II. Ortodontia. Procedimentos de Ancoragem em Orthodontia. Extração Dentária.

\section{Introduction}

Class II malocclusion - with or without related skeletal discrepancies - can have a negative impact on the facial harmony - especially due to the inherent alterations in the proportions of facial soft tissue. Currently, improvement of facial aesthetics and harmony justify the increasing search for orthodontic treatments worldwide. ${ }^{1}$

The treatment and prognosis of Class II patients depend on the aspects involved in the malocclusion. Considerations of the patient's age, the associated skeletal discrepancies, etiology, and the malocclusion severity are important in guiding the orthodontic treatment. ${ }^{2}$ Class II malocclusions may be treated with corrective orthodontics combined or not with surgical approaches, ${ }^{3}$ intraoral distalizers, ${ }^{4}$ intermaxillary elastics, ${ }^{5,6}$ and dental extractions. ${ }^{3,7-9}$ The orthodontist must be aware of differences between the treatment protocols and their applications in order to reach optimal clinical outcomes. ${ }^{3}$

Treatment with two maxillary premolars extraction is an approach indicated when the molar relationship is in full-step Class II, with no crowding and no cephalometric discrepancies in the mandibular arch. ${ }^{10}$ This protocol is efficient because it is not based on the molar relationship correction into Class I, and it also has simple biomechanics and requires shorter treatment time when compared with the 4 premolar 
extractions ${ }^{11}$ and no extractions protocols. As consequence, it may correct the malocclusion within a short time. ${ }^{4,7}$ However, its indication depends on the patient's lip thickness and tonus, the malocclusion severity, and lower anterior facial height. ${ }^{11}$

Increase in the nasolabial angle, ${ }^{12,13}$ upper lip retraction, ${ }^{4,8,12}$ and facial convexity reduction 8,12 are the cephalometric alterations related to the treatment protocol with dental extractions. Furthermore, the scientific literature ranks many other favorable outcomes from the upper premolars extraction, such as satisfactory occlusal relationships, long-term stability, and non-interference with the patient's facial profile..$^{7,10}$

Class II malocclusion treatment without dental extractions requires biomechanical alternatives. In this context, intermaxillary elastics emerged as a tool that promotes mostly dentoalveolar effects. ${ }^{5,6,9}$ Mandibular molars mesialization and extrusion, occlusal plan rotation, labial inclination of the mandibular incisors, lingual inclination, and the maxillary incisors extrusion are the effects often reported in the literature. ${ }^{3,6,9}$ A systematic review of Class II malocclusion treatment with intermaxillary elastics indicated that the effects of this therapeutic approach manifests more evidently in the mandibular arch. ${ }^{9}$ This phenomenon is justified due to the need to balance the mandibular deficiency and malocclusion. In parallel, facial harmony is impacted positively as a treatment consequence.

Improving facial aesthetics is an important part of the orthodontic treatment. Contemporary orthodontics is founded not only in malocclusions correction, but also on ensuring these corrections have a positive impact on facial harmony, phonetics, and other functional aspects. In specific cases, the available treatment approaches may be questionable depending on the consequent facial alterations promoted. ${ }^{14}$

Studies have shown alterations in facial soft tissue after treatments protocols with and without the premolars extraction using different orthodontic systems. ${ }^{3-9,11-13}$ However, the literature is scarce on the impact of intermaxillary elastics on soft tissue during the treatment of Class II malocclusion. ${ }^{9}$ The present study aimed to compare the changes in soft tissue promoted by treatment of Class II malocclusion using intermaxillary elastics with and without premolars extraction.

\section{Material and Methods}

This retrospective study was approved by the Ethical Committee in Human Research of Unisagrado - Centro Universitário Sagrado Coração (approval number 1.472.759).

The sample was selected from the dental records of postgraduate orthodontic courses. The inclusion criteria were: Class II Division 1 malocclusion with bilateral molar relationship of at least $1 / 2$ cusp treated with or without premolar extraction and intermaxillary elastics; records of available initial dental casts measurements; final dental casts presenting a canine relationship in Class I; presence of permanent teeth at least up to first molars with no dental anomalies; 5) no history of previous orthodontic treatment; 6) no or low anterior teeth crowding.

Based on the inclusion criteria, 41 patients were selected. The sample power was calculated considering the variation of the lower lip anteroposterior position between the groups (cephalometric distance Li-E-Line, mean standard deviation of $2.24 \mathrm{~mm}) .^{7}$ The sample size used in the present study had a power of $80 \%$ to detect a difference of $>2 \mathrm{~mm}$ between the two groups.

Lateral cephalometric radiographs taken before (T1) and after (T2) orthodontic treatments were collected from each patient. The sample was divided in two groups based on the treatment protocol.

Group 1 consisted of 21 patients (mean age, 18.97 years at the beginning of the treatment, totalizing 42 lateral cephalometric radiographs) who were treated with intermaxillary elastics without dental extractions for a mean period of 3.15 years. Group 2 consisted of 20 patients (mean age, 17.4 years at the beginning of the treatment, totalizing 40 lateral cephalometric radiographs) who were treated with intermaxillary elastics and extraction of two maxillary premolars for a mean period of 3.07 years.

All patients were treated by the same group of orthodontists, following the same arches sequence. Brackets Roth slots 0.022" x 0.030" (Morelli, Sorocaba-SP, Brasil) were used in all the cases. In order to correct the deep bite, the Curve of Spee was flattened by reverse stainless steel arches. The intermaxillary elastics were used first in the stainless-steel arch $(0.019 " \times 0.025 ")$ in parallel with the retraction of the maxillary anterior teeth with chain elastics. The intermaxillary elastics used measured $1 / 4$ " and $3 / 16$ " in diameter and promoted a force of nearly $150 \mathrm{~g}$. The elastics were applied from the first lower molar hook to the hook welded to the upper arch wire. The patients were informed to use the elastics continuously and to change them every two days.

The images scanned were imported in Dolphin Imaging Premium software package version 11.7 (Dolphin Imaging \& Management Solutions, Chatsworth, California, USA) for cephalometric analysis. The morphological landmarks used for cephalometric analysis followed two protocols. ${ }^{14}$ A total of 12 parameters (both linear and angular) were considered for soft tissues changes assessment.

Normality the measurements distribution was assessed with the Kolmogorov-Smirnov test. All the measurements had normal distributions. Therefore, all the mean values were compared by using parametric tests. Comparisons between groups concerning sex distribution and the severity of the malocclusion were performed with the chi-square test. The t-test was used to compare the cephalometric parameters (quantified in measurements) between the groups. Statistical analyses were performed with a significance rate of $5 \%$ $(P<0.05)$. 
In order to assess the intra-examiner agreement, twentyeight radiographs were selected randomly and re-analyzed within 30 days by the same operator. The systematic error was assessed with the paired samples t-test. The random error was assessed with the Dahlberg's formula.

\section{Results ad Discussion}

Group 1 consisted of 21 patients, out of which 11 (52.4\%) were females and $10(47.6 \%)$ were males. Group 2 consisted of 20 patients, $16(80 \%)$ females and $4(20 \%)$ males. The difference between the groups regarding sex distribution was not statistically significant $(P=0.062)$.

Table 1 shows the sample distribution based on the malocclusion severity. A balanced distribution between the groups was observed. No difference was observed between the groups concerning age at the beginning of the treatment, initial molar relationship, initial overjet, duration of treatment, and the initial cephalometric parameters (Table 2). The same table shows intergroup comparability of all the pretreatment cephalometric variables.

Table 1 - Comparison between the groups based on the Sievert malocclusion severity

\begin{tabular}{|c|c|c|c|c|c|}
\hline \multirow{2}{*}{ Severity } & \multicolumn{2}{|c|}{ Group 1 } & \multicolumn{2}{c|}{ Group 2 } & \multirow{2}{*}{ p } \\
\cline { 2 - 5 } & \multicolumn{2}{|c|}{$\mathbf{n = 2 1}$} & \multicolumn{2}{|c|}{$\mathbf{n = 2 0}$} & \\
\cline { 2 - 5 } & $\mathbf{n}$ & $\mathbf{\%}$ & $\mathbf{n}$ & $\mathbf{\%}$ & \\
\hline 1/2 Class II & 9 & 42.9 & 6 & 30 & \multirow{2}{*}{0.680} \\
\hline 3/4 Class II & 3 & 14.2 & 4 & 20 & \\
\hline Full Class II & 9 & 42.9 & 10 & 50 & \\
\hline
\end{tabular}

Group 1: patients treated without extractions; Group 2: patients treated with the extraction of two maxillary premolars; $n$ : quantity of patients; p: p-value considering a significance rate of $5 \%$.

Source: Research data.

Table 2 - Comparison between the groups based on the sample characteristics at the beginning of the treatment

\begin{tabular}{|c|c|c|c|c|c|c|}
\hline \multirow{2}{*}{ Parameter } & \multicolumn{2}{|c|}{$\begin{array}{c}\text { Group } 1 \\
(n=21)\end{array}$} & \multicolumn{2}{|c|}{$\begin{array}{c}\text { Group } 2 \\
(n=20)\end{array}$} & \multirow{2}{*}{ dif. } & \multirow{2}{*}{$\mathbf{p}$} \\
\hline & Mean & SD & Mean & SD & & \\
\hline Age (years) & 18.97 & 11.12 & 17.25 & 7.32 & 1.72 & 0.564 \\
\hline Molar Relation (mm) & 1.45 & 1.14 & 1.58 & 1.01 & 0.13 & 0.697 \\
\hline Overjet (mm) & 6.82 & 2.94 & 6.65 & 1.56 & 0.17 & 0.871 \\
\hline Treatment Time (years) & 3.15 & 1.17 & 3.07 & 0.75 & 0.08 & 0.802 \\
\hline $\operatorname{NLA}\left({ }^{\circ}\right)$ & 117.65 & 20.11 & 125.82 & 18.08 & 8.17 & 0.180 \\
\hline $\operatorname{MLA}\left({ }^{\circ}\right)$ & 115.16 & 10.56 & 119.14 & 13.03 & 3.97 & 0.289 \\
\hline $\mathrm{A}^{\prime}-\mathrm{N}^{\prime}-\mathrm{B}^{\prime}\left({ }^{\circ}\right)$ & 10.94 & 2.64 & 10.85 & 1.37 & 0.09 & 0.889 \\
\hline Ang $Z\left(^{\circ}\right)$ & 70.68 & 12.73 & 68.88 & 9.07 & 1.81 & 0.606 \\
\hline Facial convexity angle $\left(^{\circ}\right)$ & 124.24 & 5.97 & 124.74 & 2.51 & 0.50 & 0.733 \\
\hline Profile convexity angle $\left({ }^{\circ}\right)$ & 156.53 & 6.58 & 155.90 & 4.21 & 0.63 & 0.719 \\
\hline $\operatorname{U1.PP}\left({ }^{\circ}\right)$ & 26.28 & 2.95 & 28.40 & 3.60 & 2.12 & $0.038 *$ \\
\hline $\operatorname{IMPA}\left({ }^{\circ}\right)$ & 94.71 & 4.97 & 95.85 & 6.59 & 1.14 & 0.522 \\
\hline UL-E-Line (mm) & -1.75 & 3.44 & -0.92 & 2.36 & 0.83 & 0.374 \\
\hline LL-E-Line (mm) & -0.76 & 3.85 & 0.66 & 2.44 & 1.42 & 0.170 \\
\hline $\begin{array}{c}\text { UL Protr } \\
(\text { Sn-Pog'-UL) (mm) }\end{array}$ & 3.29 & 2.97 & 3.18 & 2.57 & 0.11 & 0.904 \\
\hline $\begin{array}{c}\text { LL Protr } \\
\text { (Sn-Pog'-LL) (mm) }\end{array}$ & -1.30 & 3.90 & -0.39 & 2.81 & 0.92 & 0.396 \\
\hline
\end{tabular}

SD: standard deviation; p-value considering a significance rate of $5 \%$.

Source: Research data.

The outcomes of the intra-examiner agreement tests were assessed with the paired t-test and Dahlberg's formula. The comparison between the first and second analyses revealed low random error and no systematic error (minimum of $0.43^{\circ}$ for $\mathrm{A}^{\prime}-\mathrm{N}^{\prime}-\mathrm{B}^{\prime}$ and maximum of $2.56^{\circ}$ for nasolabial angle (NLA).

Table 3 shows the variation between $\mathrm{T} 1$ and $\mathrm{T} 2$ for each cephalometric parameter considered in the present study. In Group 1, the distance between the lower lip and reference line $\mathrm{E}$ (LL-E-Line) increased in average $0.09 \mathrm{~mm}$. In Group 2 , an average decrease of $1.59 \mathrm{~mm}$ was observed in the same distance $(P<0.05)$. Difference in facial convexity was also observed - increasing in Group 1 (mean increase of $1.73^{\circ}$ ) and decreasing in Group 2 (mean decrease of $\left.0.68^{\circ}\right)(P<0.05)$. 
Table 3 - Comparison of changes treatment means (T2-T1) in both groups.

\begin{tabular}{|c|c|c|c|c|c|c|}
\hline \multirow{2}{*}{ Parameter } & \multicolumn{2}{|c|}{ Group 1} & \multicolumn{2}{|c|}{ Group 2} & \multirow{2}{*}{ dif. } & \multirow{2}{*}{$\mathbf{p}$} \\
\hline & Mean & SD & Mean & SD & & \\
\hline $\operatorname{NLA}\left({ }^{\circ}\right)$ & 6.77 & 21.09 & -0.43 & 22.03 & 7.20 & 0.291 \\
\hline $\operatorname{MLA}\left({ }^{\circ}\right)$ & 8.36 & 17.23 & 7.47 & 10.58 & 0.89 & 0.844 \\
\hline $\mathrm{A}^{\prime}-\mathrm{N}^{\prime}-\mathrm{B}^{\prime}\left({ }^{\circ}\right)$ & -2.12 & 1.93 & -2.09 & 1.79 & 0.04 & 0.947 \\
\hline 6.27 & 3.06 & & 4.58 & 6.97 & 1.52 & 0.466 \\
\hline 3.66 & 1.73 & & -0.68 & 3.19 & 2.40 & $0.031 *$ \\
\hline Profile convexity angle $\left({ }^{\circ}\right)$ & 2.46 & 3.94 & 2.60 & 3.20 & 0.14 & 0.903 \\
\hline $\mathrm{U} 1 . \mathrm{PP}\left({ }^{\circ}\right)$ & 0.90 & 1.81 & 0.01 & 1.51 & 0.89 & $0.085^{*}$ \\
\hline $\operatorname{IMPA}\left({ }^{\circ}\right)$ & 8.07 & 8.08 & 4.99 & 6.16 & 3.08 & 0.163 \\
\hline UL-E-Line (mm) & -1.36 & 3.41 & -2.38 & 2.12 & 1.02 & 0.261 \\
\hline LL-E-Line (mm) & 0.09 & 2.54 & -1.59 & 1.93 & 1.68 & $0.022 *$ \\
\hline $\begin{array}{c}\text { UL Protr } \\
\text { (Sn-Pog'-UL) (mm) }\end{array}$ & -1.52 & 2.17 & -1.23 & 2.06 & 0.29 & 0.659 \\
\hline $\begin{array}{c}\text { LL Protr } \\
(\text { Sn-Pog'-LL) (mm) }\end{array}$ & 0.97 & 3.12 & 0.19 & 2.55 & 0.78 & 0.390 \\
\hline
\end{tabular}

SD: standard deviation; p: p-value considering a significance rate of 5\%; *: statistically significant differences.

Source: Research data.

The soft tissue changes caused by the treatment of Class II malocclusion are described broadly in the scientific literature. ${ }^{4-9,11-13}$ However, studies on the influence of only intermaxillary elastics on soft tissue alterations are scarce. ${ }^{9}$ Therefore, the present study aimed to compare the alterations in facial soft tissue after the treatment of Class II malocclusion using intermaxillary elastics with and without the extraction of 2 maxillary premolars.

Sampling two groups with high compatibility is an essential procedure for quality control in cephalometric investigations. ${ }^{7}$ As shown in Table 3, the similarity between the groups was confirmed for all the characteristics of interest: initial age at the treatment, initial overjet, initial molar relation, treatment duration, and initial cephalometric measurements (Figure 1). The two different approaches were chosen based on facial profile and the malocclusion severity, including crowding observed at the initial exams. Both protocols are highly described and consolidated in the literature. ${ }^{3-5,7,8}$

Figure 1 - Initial and final means superimposition (with extractions)

$=0$
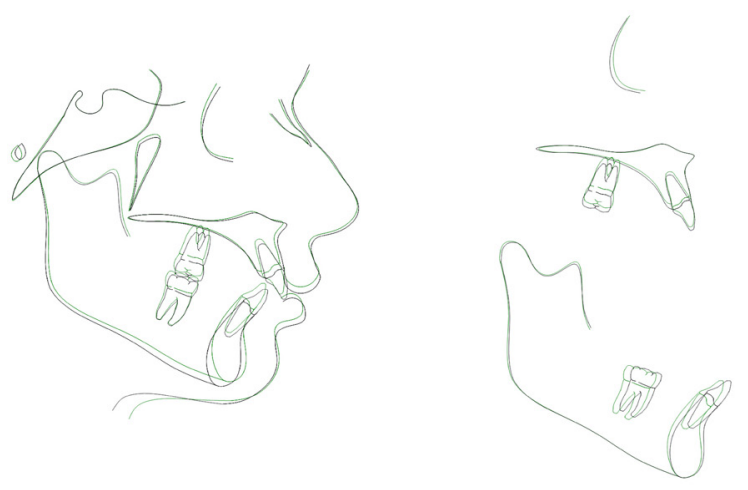

Source: The authors.

Based on the two cephalometric variables, the most prominent point on the upper lip was retracted after treatment in both groups. First, the distance between the upper lip and the Ricketts' aesthetic plane (UL-E-Line) had a mean alteration of $-1.36 \mathrm{~mm}$ in Group 1 and $-2.38 \mathrm{~mm}$ in Group 2. Second, lip retraction was also observed considering the parameter UL Protr, in which the line Sn-Pog' was used as reference. In Group 1, the mean lip retraction was $-1.52 \mathrm{~mm}$, while in Group 2 it was $-1.23 \mathrm{~mm}$. Lip positioning after the treatment of Class II malocclusion may vary considerably because it depends on the dentoalveolar alterations promoted by the mechanical system applied. ${ }^{7,13,14,17}$ Moreover, lip thickness is identified as a factor that also influences lip positioning after the treatment. ${ }^{14}$ In the present study, the variation of the upper incisors inclination after the treatment was statistically significantly higher in the group without extractions compared to the group with extractions. (Figure 2) This is probably due to the presence of a greater crowding in this region in Group 2 , reason for choosing the extraction approach.

Figure 2 - Initial and final means superimposition (no extractions)
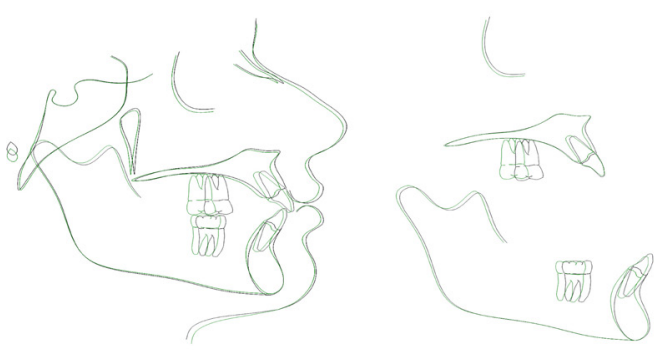

Source: The authors.

In both groups, the mean overjet before treatment was 6 $\mathrm{mm}$. After correcting the maxillary incisors inclination and improving the relationship of the anterior teeth, the upper lip tended to retract similarly in the treatment with or without dental extractions. ${ }^{15}$ (Figure 3 ) Table 4 shows two statistically significant differences between the groups. After treatment, 
the parameter LL-E-Line had a mean increase of $0.09 \mathrm{~mm}$ in Group 1. This suggests a discrete protrusion of the lower lip in patients treated without extractions. ${ }^{5,7}$ (Figure 4) In Group 2 , the mean alteration of $-1.59 \mathrm{~mm}$ was observed, which is interpreted as the lower lip retraction. This finding was also observed in previous studies., 7, 8, 16 The scientific literature shows that intermaxillary elastics promote labial inclination of the mandibular incisors. ${ }^{5,9,15}$ This alteration influences directly the lower lip position, which protracts and improves the relation with the upper lip. (Figure 5)

Figure 3 - Final means overlapping, with and without extractions

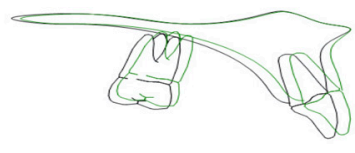

With extractions

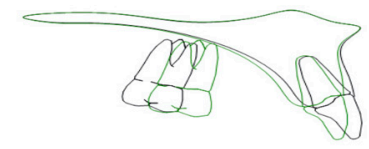

No extractions
Source: The authors.

Figure 4 - Initial means overlapping, with and without extractions

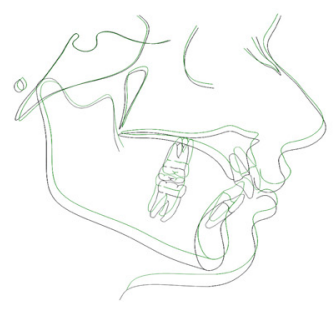

Source: The authors.

Figure 5 - Maxillary dentoalveolar changes

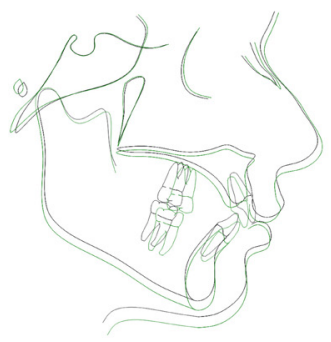

Source: The authors.

According to Ricketts, LL-E-Line measuring $-3.0 \mathrm{~mm}$ (standard deviation: $2.0 \mathrm{~mm}$ ) is considered normal for young patients. ${ }^{16}$ The anatomic reference for this parameter is the most prominent point of the lower lip. In most patients with Class II malocclusion, the lower lip is everted and apparently protracted due to overjet and overbite increase. Eventually, the lower lip is positioned between the maxillary and mandibular anterior teeth. However, the lip returns to the normal position after overjet correction. ${ }^{16}$ It is possible to explain the negative value in LL-E-Line on the increasing distance between the E-Line and the lower lip. This alteration follows the nose development and the pogonion forward and downward. ${ }^{17,18}$

Facial convexity (represented by the angle N'-SnPog') was also statistically significantly different between the two groups $\left(+1.73^{\circ}\right.$ in Group 1 and $-0.68^{\circ}$ in Group 2). These outcomes differ from other study. ${ }^{18}$ Specifically, the authors observed a decrease in facial convexity in both groups without reaching statistically significant differences. It is important to note that the authors sampled patients that underwent the extraction of four premolars instead of two, as used in the present study. Possibly, the stronger need for using intermaxillary elastics in Group 1 explains the major variation in facial convexity $\left(+1.73^{\circ}\right)$ in this group compared to Group $2\left(-0.68^{\circ}\right)$. This alteration is also because of the effects that the intermaxillary elastics have on the position of the cephalometric landmark Pog'. ${ }^{16}$

Facial soft tissue changes that result from dental movements cannot be determined, but only estimated. According to the scientific literature, the soft tissue alterations from the treatment of Class II malocclusions using intermaxillary elastics are more evident in the mandibular arch - with or without extractions. ${ }^{9}$ The lower lip protraction is one of the most evident alterations. This alteration, combined with the facial convexity reduction, may positively impact the facial harmony. This observation has clinical relevance regarding the facial results. In addition, excellent occlusal results can be achieved in the Class II treatment with intermaxillary elastics.

\section{Conclusion}

According to the results described in this study:

- There are similarities in profile soft tissue changes produced by both Class II treatment protocols, with and without extractions associated to intermaxillary elastics.

- The exceptions are those of the facial convexity (N'Sn-Pog ') that decreased in the protocol without extractions and the inferior lip position (Li-Line E) that retracted in the protocol with extractions.

\section{Availability of data and materials}

The datasets used and/or analyzed during the current study are available from the corresponding author on reasonable request.

\section{References}

1. Edler R, Agarwal P, Wertheim D, Greenhill D. The use of anthropometric proportion indices in the measurement of facial attractiveness. Eur J Orthod 2006;28(3):274-81. doi:10.1093/ejo/cji098

2. Rosenblum RE. Class II malocclusion: mandibular retrusion or maxillary protrusion?. Angle Orthod 1995;65(1):49-62. doi: $\quad$ 10.1043/0003-3219(1995)065<0049:CIMMRO >2.0 $\mathrm{CO} ; 2$

3. Jones G, Buschang PH, Kim KB, Oliver DR. Class II nonextraction patients treated with the forsus fatigue resistant device versus intermaxillary elastics. Angle Orthod 
2008;78(2):332-8. doi: 10.2319/030607-115.1

4. de Almeida-Pedrin RR, Henriques JF, de Almeida RR, de Almeida MR, McNamara JÁ. Effects of the pendulum appliance, cervical headgear, and 2 premolar extractions followed by fixed appliances in patients with Class II malocclusion. Am J Orthod Dentofac Orthop 2009;136(6):833-42. doi: 10.1016/j.ajodo.2007.12.032

5. Combrink FJ, Harris AM, Steyn CL, Hudson AP. Dentoskeletal and soft-tissue changes in growing class II malocclusion patients during nonextraction orthodontic treatment. SADJ 2006;61(8):344-50.

6. Nelson B, Hansen K, Hägg U. Class II correction in patients treated with Class II elastics and with fixed functional appliances: A comparative study. Am J Orthod Dentofacial Orthop 2000;118(2):142-9. doi: 10.1067/mod.2000.104489

7. Janson G, Fuziy A, de Freitas MR, Castanha Henriques JF, de Almeida RR. Soft-tissue treatment changes in Class II Division 1 malocclusion with and without extraction of maxillary premolars. Am J Orthod Dentofacial Orthop 2007;132(6):729e1-8. doi: 10.1016/j.ajodo.2007.05.012

8. Seben MP, Valarelli FP, de Freitas KM, Cançado RH, Bittencourt Neto AC. Cephalometric changes in Class II division 1 patients treated with two maxillary premolars extraction. Dent Press J Orthod. 2013;18(4):61-9. doi: $10.1590 /$ s2176-94512013000400010

9. Janson G, Sathler R, Fernandes TM, Branco NC, Freitas MR. Correction of Class II malocclusion with Class II elastics: a systematic review. Am J Orthod Dentofacial Orthop 2013;143(3):383-92. doi: 10.1016/j.ajodo.2012.10.015

10. Janson G, Brambilla Ada C, Henriques JF, de Freitas MR, Neves LS. Class II treatment success rate in 2- and 4-premolar extraction protocols. Am J Orthod Dentofacial
Orthop 2004;125(4):472-9. doi: 10.1016/j.ajodo.2003.04.013

11. Janson G, Mendes LM, Junqueira CH, Garib DG. Softtissue changes in Class II malocclusion patients treated with extractions: a systematic review. Eur J Orthod 2016:38(6):631-637. doi: 10.1093/ejo/cjv083

12. Scott Conley R, Jernigan C. Soft Tissue Changes after Upper premolar extraction in class II camouflage therapy. Angle Orthod 2006;76(1):59-65. doi: 10.1043/0003-3219(2006)076[0059:STCAUP]2.0.CO;2

13. Tadic N, Woods MG. Incisal and soft tissue effects of maxillary premolar extraction in class II treatment. Angle Orthod 2007;77(5):808-16. doi: 10.2319/081706-336

14. Arnett GW, Bergman RT. Facial keys to orthodontic diagnosis and treatment planning. Part I. Am J Orthod Dentofacial Orthop 1993;103(4):299-312. doi: 10.1016/08895406(93)70010-L

15. Maetevorakul S, Viteporn S. Factors influencing soft tissue profile changes following orthodontic treatment in patients with Class II Division 1 malocclusion. Prog Orthod 2016;17(1):13. doi: 10.1186/s40510-016-0125-1

16. Verma SL, Sharma VP, Tandon P, Singh GP, Sachan K. Comparison of esthetic outcome after extraction or nonextraction orthodontic treatment in class II division 1 malocclusion patients. Contemp Clin Dent 2013;4(2):206-12. doi: 10.4103/0976-237X.114886

17. Bishara SE, Jakobsen JR, Hession TJ, Treder JE. Soft tissue profile changes from 5 to 45 years of age. Am J Orthod Dentofacial Orthop 1998;114(6):698-706. doi: 10.1016/ s0889-5406(98)70203-3

18. Finnoy JP, Wisth PJW, Boe OE. Changes in soft tissue profile during and after orthodontic treatment. Eur J Orthod 1987;9(1):68-78. doi: 10.1093/ejo/9.1.68 